\title{
Raised Serum IgG Levels in Hypertension
}

\author{
A. EBRINGER,* M.B., B.SC., M.R.A.C.P. ; A. E. DOYLE, $†$ M.D., F.R.C.P., F.R.A.C.P.
}

Cummary: Serum IgG levels were significantly higher $\checkmark$ in 118 severely hypertensive patients compared with a group of 163 normotensive blood donors, matched for age and sex. Serum IgA and IgM were the same in both groups. Raised levels of serum IgG were found in patients who had never been treated for hypertension, as well as in those who were treated with methyldopa or other hypotensive drugs.

It is suggested that the raised levels of serum IgG may be an index of vascular damage induced by hypertension.

\section{Introduction}

Immunological reactions occurring after tissue injury have not previously been studied extensively, though Weir $(1966,1967)$ suggested that subcellular components may induce the formation of tissue reactive immunoglobulins after cell death. In acute tissue damage which follows prostatic cryosurgery there is a drop in the serum level of immunoglobulin $G$ (IgG) (Drylie et al., 1968), while chronic tissue damage, like that occurring in seropositive rheumatoid arthritis, is associated with raised serum IgG (Marcolongo et al., 1967). The causes of these changes in immunoglobulin levels are not known, but it has been suggested that they are due either to an associated mild subclinical infection or to the release of antigenic material from necrotic tissue which evokes an immunological response.

In many hypertensive patients the histological changes consistent with tissue damage are found in the walls of blood vessels (Kincaid-Smith et al., 1958). Fibrinoid necrosis of small arteries and arterioles occurs in malignant hypertension, and the fibrinoid material contains gammaglobulin (Paronetto, 1965). It is possible that high blood pressure leads to vascular tissue necrosis, which could evoke an immunological response and produce a change in serum levels of immunoglobulins. Raised levels of immunoglobulins in patients with arteritis of the aorta and great vessels have been reported by Asherson et al. (1968).

The present study reports a comparison of the levels of immunoglobulins in patients with severe hypertension and a group of normotensive blood donors.

\section{Materials and Methods}

Hypertensive Patients.-Patients attending the outpatient hypertensive clinics at the Austin Hospital and Repatriation General Hospital, Heidelberg, or inpatients with hypertension in the professorial units were studied. Hypertensive patients with a standing mean blood pressure (diastolic blood pressure plus a third of the pulse pressure) of $130 \mathrm{~mm}$. $\mathrm{Hg}$ or more on at least one occasion were included. Of 118 patients studied, 98 had essential hypertension, 11 had malignant hypertension, and 9 had hypertension with renal disease of various aetiologies, such as pyelonephritis or glomerulonephritis. All patients with diseases known to cause alteration in the immunoglobulin levels were excluded. After clinical assessment venous blood was allowed to clot at room temperature, centrifuged, and the serum separated and stored at $-10^{\circ} \mathrm{C}$ Most patients also had the following tests done: haemoglobin,

*N.H. and M.R.C. Research Officer in the Department of Medicine, University of Melbourne, Austin Hospital, Heidelberg, Victoria, Australia.

†Professor of Medicine, University of Melbourne, Austin Hospital, Heildelberg, Victoria, Australia. erythrocyte sedimentation rate, plasma electrolytes, and blood urea. Direct Coombs test was performed on 42 patients who had previously received methyldopa.

Controls.-The controls were 163 healthy blood donors with systolic blood pressure less than $160 \mathrm{~mm}$. $\mathrm{Hg}$ attending the blood bank at the Repatriation General Hospital, Heidelberg. The blood was separated and serum stored in the same manner as for hypertensive patients.

$\operatorname{IgG}, \operatorname{Ig} A$, and $\operatorname{IgM}$ Estimations.-Serum $\operatorname{IgG}, \operatorname{IgA}$, and IgM estimations were determined by the radial immunodiffusion technique (Fahey and McKelvey, 1965) with commercially prepared immunodiffusion plates and protein standards (Hyland Laboratories).

\section{Results}

\section{Immunoglobulins $G ; A$, and $M$}

The mean serum IgG in 118 hypertensive patients was 1,568 ( \pm 370 S.D.) $\mathrm{mg} . / 100 \mathrm{ml}$. The mean serum IgG in 163 normotensive blood donors was 1,259 ( \pm 306 S.D.) $\mathrm{mg} . / 100$ $\mathrm{ml}$. This difference was statistically significant $(t=7.61$, $\mathrm{P}<0.001$ ). The frequency distribution of the two groups (Fig. 1) showed considerable overlap in serum immunoglobulin levels, but the median populations were quite distinct. There was no significant difference in the serum levels of IgA and IgM between hypertensive patients and blood donors (Fig. 2). The

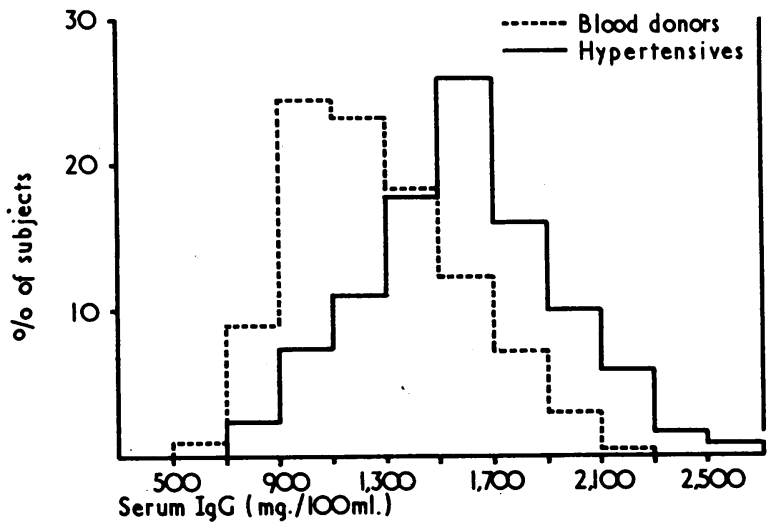

FIG. 1.-Frequency distribution of serum IgG in hypertensives and blood donors.

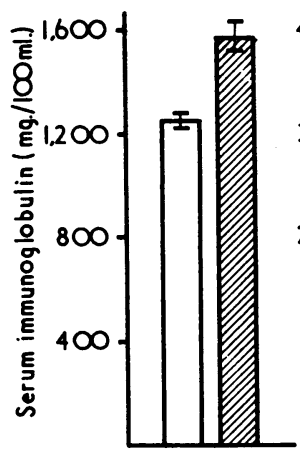

$\mathrm{IgC}$

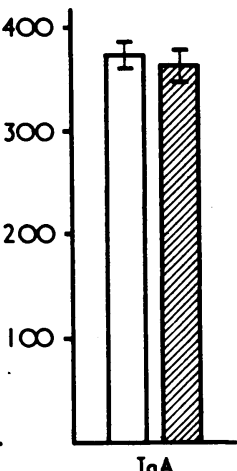

$\operatorname{Ig} A$

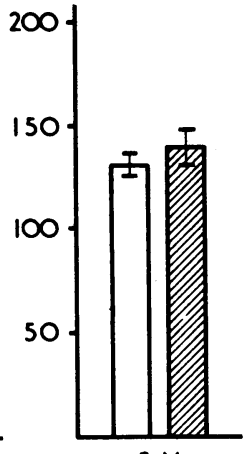

IgM
FIG. 2.-Mean and standard error of mean of serum immunoglobulins in hypertensives (stippled columns) and blood donors 
mean serum IgA in 62 hypertensive patients was 363 ( \pm 115 S.D.) mg. $/ 100 \mathrm{ml}$, while the mean serum IgA in 99 blood donors was 373 ( \pm 142 S.D.) mg. $/ 100 \mathrm{ml}$. The mean serum $\mathrm{IgM}$ in 68 hypertensive patients was 139 ( \pm 75 S.D.) $\mathrm{mg} . / 100$ ml. while the mean serum IgM in 146 hypertensive patients was 131 ( \pm 66 S.D.) mg./100 ml. There was a complete absence of IgA in one hypertensive patient and in two blood donors. This frequency agrees with other reports in the literature (Bachmann, 1965), and these three zero values were not included in the estimations of the mean and standard deviations of IgA.

\section{Age and Sex}

The average age of the blood donors was 41.95 years (range 18 to 62 years) while that of the hypertensive patients was 52.0 years (range 7 to 76 years). In neither group was a significant statistical correlation found between age and the level of IgG. To assess further the effect of age the differences in serum IgG between hypertensive patients and blood donors were compared for each decade. Only groups containing more than three subjects per decade were used in the comparison. There was no obvious rise with age either in the male blood donors or in the male hypertensives (Fig. 3). There was,

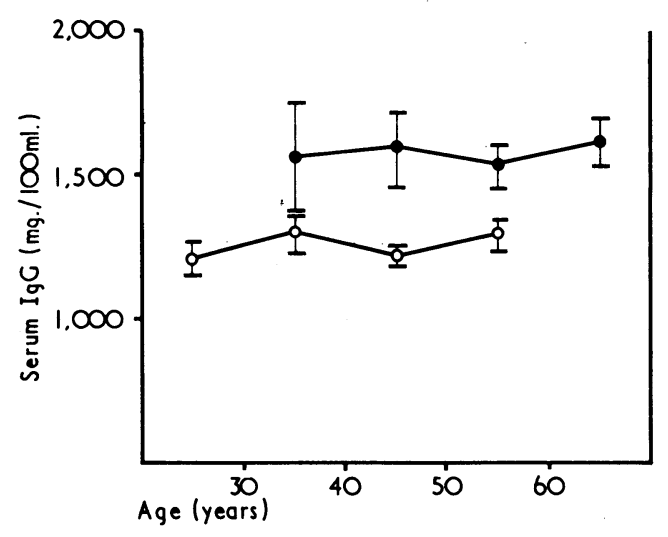

FIG. 3.-Serum IgG and age in male hypertensives (O) compared with normotensive blood donors $(O)$. Grouped averages of serum IgG with standard errors of mean are shown for each decade. Only groups having more than three subjects per decade have been included in this comparison.

however, a statistically significant difference between the serum IgG levels in male hypertensives and blood donors in the two decades 40-49 and 50-59 years. The mean serum IgG in 15 male hypertensive patients aged 40-49 was 1,594 ( \pm 495 S.D.) mg. $/ 100 \mathrm{ml}$. while in 65 male blood donors in the same age group it was 1,217 ( \pm 294 S.D.) mg./100 ml. $(t=3.86, \mathrm{P}<0.01)$. The mean serum IgG in 24 male hypertensive patients aged 50-59 was 1,534 ( \pm 375 S.D.) mg./100 ml., while in 37 male blood donors in the same group it was 1,286 ( \pm 336 S.D.) mg. $/ 100 \mathrm{ml}$. $(t=2.65, \mathrm{P}<0.02)$.

There were 67 male and 51 female hypertensive patients. The average serum IgG was $1,558 \mathrm{mg} . / 100 \mathrm{ml}$. in male patients and $1,583 \mathrm{mg} . / 100 \mathrm{ml}$. in female patients; the difference was not statistically significant. There were 148 male blood donors and only 15 female blood donors. The average serum IgG level in male blood donors was $1,255 \mathrm{mg} . / 100 \mathrm{ml}$. and in female blood donors it was $1,294 \mathrm{mg} . / 100 \mathrm{ml}$; the difference was not statistically significant.

There was a significant statistical difference in the serum IgG levels between the 148 male blood donors and the 67 male hypertensive patients $(t=6.11, P<0.001)$ as well as between the 15 female blood donors and the 51 female hypertensive patients $(t=2.93, \mathrm{P}<0.005)$.

\section{Hypertension}

Duration.-The duration of hypertension was estimated retrospectively either from an actual record of a raised blood pressure or from the start of hypotensive therapy (range 1 to 20 years). No significant correlation was found between estimated duration of hypertension and the serum IgG level.

Type.-The mean serum IgG level in essential hypertension was $1,573 \mathrm{mg} . / 100 \mathrm{ml}$. (98 patients), in renal hypertension $1,443 \mathrm{mg} . / 100 \mathrm{ml}$. (8 patients), and in malignant hypertension $1,664 \mathrm{mg} . / 100 \mathrm{ml}$. (10 patients). There was no statistically significant difference in the serum IgG level between these various types of hypertension. Though there was some association between the degree of fundal changes as assessed on a Keith-Wagener scale and serum IgG, it was not statistically significant.

\section{Previous Treatment}

Sixty-seven patients had been treated with methyldopa, usually with diuretics; 24 had never received methyldopa but had been treated with other hypotensive drugs such as reserpine, diuretics, and guanethidine; 21 patients had never been treated for hypertension; and in six patients the presence or absence of previous treatment could not be ascertained.

The average serum IgG in these three groups of hypertensives was raised compared with the normotensive blood donor population (Fig. 4), and this difference was statistically sig-

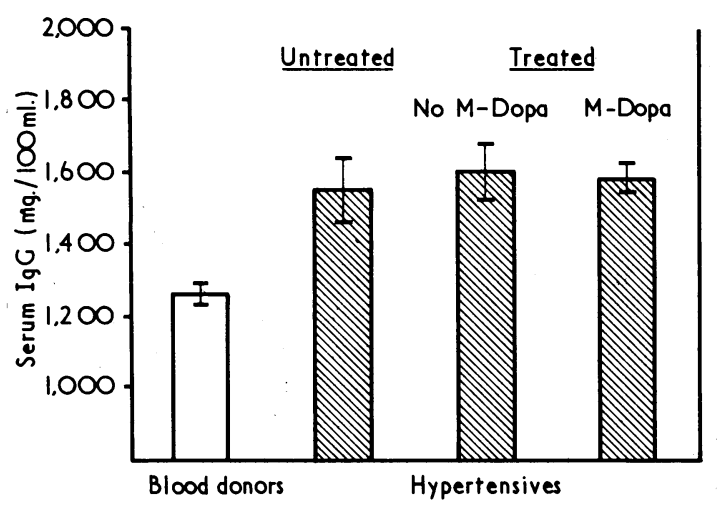

FIg. 4.-Serum IgG in hypertensives and blood donors are compared with previous hypotensive therapy. Averages with their standard error of the mean are shown for each group.

nificant. The mean serum $\operatorname{IgG}$ in 21 untreated hypertensives was 1,550 ( \pm 394 S.D.) $\mathrm{mg} . / 100 \mathrm{ml}$. ( $t=3.93, \mathrm{P}<0.001)$, in 24 patients previously treated with hypotensive drugs other than methyldopa it was 1,599 ( \pm 361 S.D.) mg. $/ 100 \mathrm{ml}$. $(t=4.93$ $P<0.001$ ), and in 67 patients previously treated with methyldopa and other drugs it was 1,582 ( \pm 362 S.D.) mg./100 ml. $(t=6.82, P<0.001)$. There was no significant difference in serum IgG between the three groups of hypertensives.

\section{Other Tests}

There was no statistically significant correlation between the serum IgG level and haemoglobin, blood urea, plasma electrolytes, and erythrocyte sedimentation rate in the hypertensive patients.

Direct Coombs Test.-The direct Coombs test was performed in 42 patients who had previously been treated with methyldopa. It was positive in four patients and negative in 38. Thus $9.5 \%$ of patients taking methyldopa had a positive direct Coombs test. None of these patients had any evidence of haemolytic anaemia. The average serum IgG in these four patients having a positive direct Coombs test was 1,458 mg./ 
$100 \mathrm{ml}$., which was not significantly different from the findings in those patients having a negative direct Coombs test.

\section{Discussion}

Serum IgG has been found to be raised in a group of patients with severe hypertension, whereas the serum IgA and IgM levels were the same in both hypertensive patients and blood donors. The rise in serum IgG was independent of age, sex, and duration of the disease or type of hypertension.

The cause of the raised serum IgG in hypertension is not clear, but the most likely explanation is that the rise occurs as a result of vascular damage induced by the raised blood pressure. In support of this view, Ohta et al. (1959) found specific binding of rat gammaglobulin in vascular tissue of rats rendered hypertensive by unilateral nephrectomy and deoxycortone. It has also been shown by Olsen (1969) that hypertension leads to the fragmentation of the internal elastic lamina. Hypertension thus might lead to vascular damage, which could be associated with the release of connective tissue components and which may become antigenic, as suggested by Weir (1967). Such antigens in turn could cause a rise in the level of antibodies required for opsonization of tissue debris and cellular fragments to be eliminated by macrophages, through the usual process of inflammation. This rise in antibodies would then be reflected in raised levels of serum IgG.

A rise in serum IgG occurs in other diseases involving chronic tissue damage, such as rheumatoid arthritis (Veys and Claessens, 1968), chronic liver disease (Auper et al., 1966), arteritis of aorta and great vessels (Asherson et al., 1968), and polymyalgia arteritica (Hamrin et al., 1965).

The concept of autoantibody association with tissue damage is not new. It was first suggested by Ehrlich in 1901 (Ehrlich and Morgenroth, 1957) and Weil and Braun (1907), and later reaffirmed by Grabar (1957), Boyden (1962), and Weir (1967). The presence of autoantibodies following tissue damage has been found in burns against skin (Pavkova, 1962; Ablin et al., 1969) and in myocardial infarction against cardiac tissue (Ehrenfeld et al., 1961).

The presence of autoantibodies against vascular tissue has been shown in hypertensive patients by Köröskényi et al. (1961), using a complement-consumption test, and in hypertensive animals by White and Grollman (1964), who showed the presence of precipitins against arterial wall by the gel double-diffusion technique. Rises in autoantibodies to vascular tissue may be responsible for the rise in serum IgG found in severely hypertensive patients. It is thus possible that immunological criteria may provide an index of vascular damage present in hypertension. An alternative hypothesis is that the presence of these raised levels of immunoglobulins precedes the onset of hypertension. If this is so it would imply that they are somehow a factor, among many others, in the pathogenesis of hypertension as suggested by Okuda and Grollman (1967). There is little evidence at present to support this concept.

It is unlikely that the rise in serum IgG in hypertensive patients is related to the effect of treatment, though patients taking methyldopa may develop a positive direct Coombs test
(Carstairs et al., 1966; Louis et al., 1967) and sometimes haemolytic anaemia (Worlledge et al., 1966). Both those patients taking hypotensive drugs and untreated patients had raised levels of serum IgG when compared with normotensive blood donors.

Moreover, patients previously treated with methyldopa did not have higher levels of serum IgG than those who had never taken this drug. The presence of a positive direct Coombs test in a small group of patients was not associated with an increased level of serum IgG when compared with patients giving a negative response to the direct Coombs test. Owing to the small number of patients with a positive direct Coombs test, however, no valid statistical inferences can be drawn. Whether methyldopa intake leads to increased levels of circulating IgG remains unanswered by this investigation, but it is clear that it is not the cause of the raised levels of IgG found in hypertension.

We wish to acknowledge the technical assistance of Miss $\mathrm{L}$. Doherty and Miss J. Neeson. We also wish to thank Mr. B. McC. Jones, of the Repatriation General Hospital, Heidelberg, for assistance in carrying out this investigation.

\section{REFERENCES}

Ablin, R. J., Milgrom, F., Kano, K., Rapaport, F. T., and Beutner, E. H. (1969). Vox Sanguinis, 16, 73

Alper, C. A., Rosen, F. S., and Janeway, C. A. (1966). New England fournal of Medicine, 275, 591 .

Asherson, R. A., Asherson, G. L., and Schrire, V. (1968). British Medical fournal, 3, 589.

Bachmann, R. (1965). Scandinavian fournal of Clinical and Laboratory Investigation, 17, 316.

Boyden, S. V. (1962). Nature, 201, 200.

Carstairs, K. C., Breckenridge, A., Dollery, C. T., and Worlledge, S. M. (1966). Lancet, 2, 133.

Drylie, D. M., Jordan, W. P., and Robbins, J. B. (1968). Investigative Urology, 5, 619.

Ehrenfeld, E. N., Gery, I., and Davies, A. M. (1961). Lancet, 1, 1138.

Ehrlich, P., and Morgenroth, J. (1957). In The Collected Papers of Paul Ehrlich, vol. 2, edited by F. Himmelweit, p. 234. London, Pergamon. 84.

Fahey, J. L., and McKelvey, E. M. (1965). fournal of Immunology, 94,

Grabar, P. (1957). Texas Reports on Biology and Medicine, 15, 1.

Kincaid-Smith, P., McMichael, J., and Murphy, E. A. (1958). Quarterly fournal of Medicine, 27, 117

Köröskényi, K., Juba, F., and Vajda, G. (1961). Experientia, 17, 91.

Louis, W. J., Doyle, A.' E., Jerums, G., and Kincaid-Smith, P. (1967). Medical Fournal of Australia, 2, 104 .

Marcolongo, R., Carcassi, A., Frullini, F., Bianco, G., and Bravi, A. (1967). Annals of the Rheumatic Diseases, 26, 412

Ohta, G., Cohen, S., Singer, E. J., Rosenfield, R., and Strauss, L. (1959). Proceedings of the Society for Experimental Biology and Medicine, 102, 187.

Okuda, T., and Grollman, A. (1967). Texas Reports on Biology and Medicine, 25, 257.

Olsen, F. (1969). Acta Pathologica et Microbiologica Scandinavica, 75, 527.

Paronetto, F. (1965). American fournal of Pathology, 46, 901.

Paronetto, F. (1965). American fournal of Pat

Veys, E. M., and Claessens, H. E. (1968). Annals of the Rheumatic

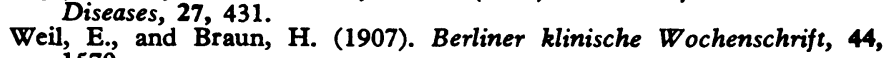
1570 .

Weir, D. M. (1966). In Research in Burns, edited by A. B. Wallace and A. W. Wilkinson, p. 389. Edinburgh, Livingstone.

Weir, D. M. (1967). Lancet, $2,1071$.

White, F. N., and Grollman, A. (1964). Archives of Pathology, 78, 31.

Worlledge, S. M., Carstairs, K. C., and Dacie, J. V. (1966). Lancet, 2, 135. 